\title{
Joanna Puppel, Obecność i rola gestów rytualnych w przestrzeni publicznej. Analiza rzeźb sakralnych w świątyniach katolickich na terenie miasta Poznania i wybranych okolic, Wydawnictwo Naukowe UAM, Poznań 2014, ss. 565
}

Joanna Puppel, poznańska anglistka i ekolingwistka, wydała monografię, o której wartości stanowią $\mathrm{w}$ moim przekonaniu przede wszystkim następujące względy i okoliczności:
A. Wybór tematu
O ile badania nad komunikacją niewerbalną, w tym badania w zakresie sub- dyscypliny komunikologicznej, którą można by określić mianem „gestologii”, mają już długą tradycję i znaczące osiągnięcia w nauce zachodnioeuropejskiej i amerykańskiej, o tyle na gruncie polskim takie badania wciąż jeszcze trzeba traktować jako w mniejszym lub większym stopniu pionierskie. A już abso- lutnie pionierska jest na polskim gruncie przedsięwzięta przez poznańską lin- gwistkę próba analizy obecności i roli gestów rytualnych na przykładzie rzeźb sakralnych w przestrzeni świątyni katolickiej. Autorka ma więc pełne prawo do satysfakcji płynącej z podjęcia nowego w nauce zagadnienia w sposób nowatorski i oryginalny.

B. Solidna podstawa źródłowo-materiałowa

Badaczka poddała oryginalnej (według gruntownie przemyślanej procedury) analizie (własnoręcznie sfotografowane w latach 2011/2012) rzeźby (stojące postaci Jezusa, Maryi, aniołów i świętych) znajdujące się w wybranych kościołach w Poznaniu i okolicach w imponującej liczbie 352 rzeźb wewnątrzświątynnych i 64 rzeźb okołoświątynnych. Jest to liczba w pełni umożliwiająca zasadne uogólnienia. 
C. Adekwatne do zgromadzonego materiału badawczego synkretyczne (polimetodologiczne) założenia teoretyczno-metodologiczne i instrumentarium badawcze

Sama autorka pisze o tym, co następuje:

W celu pełniejszego omówienia gesturalności rytualnej autorka nie tylko umiejscowiła swoją pracę w perspektywie komunikologicznej i gestologicznej, ale także posłużyła się elementami metodologii przyjętej i rozwiniętej przez podejście strukturalistyczne. Pozwoliło ono spojrzeć na zagadnienie gesturalnej ekspresji rytualnej przez pryzmat strukturalno-funkcjonalny, uwzględniający trzy następujące i wzajemnie uzupełniające się płaszczyzny: płaszczyznę uniwersalnego systemu gesturalnego (USG) - obejmującą całokształt gesturalności człowieka, płaszczyznę matrycy użycia gestów (MUG) pozwalającą na dość precyzyjne określenie charakteru, tj. dystrybucji ułożenia poszczególnych gestów w odniesieniu do schematu wyprostowanej postawy człowieka, oraz płaszczyznę charakteryzujących każdy gest wiązek/zestawów cech dystynktywnych. Taki sposób prezentacji zagadnienia pozwala spojrzeć na gesturalność, w tym gesturalność rytualną jako na zachowania wręcz zdeterminowane przez określoną gramatykę gestów. Ta ostatnia stanowi, zdaniem autorki niniejszego opracowania, jądro kompetencji kulturowo-gesturalnej komunikatorów ludzkich. Jako taka stanowi w sposób zupełnie oczywisty naturalną część kompetencji kulturowo-językowo-komunikacyjnej człowieka, którą on dysponuje i do której ma nie tylko dostęp, ale się do niej nieustannie odnosi w swoich, jakże zróżnicowanych, zachowaniach z użyciem zasobów niewerbalnych. [Puppel 2014: 543]

Szkoda tylko, że ta eksplicytna deklaracja teoretyczno-metodologiczna znalazła się dopiero we wnioskach końcowych, podczas gdy - moim zdaniem powinna zamykać pierwszą część pracy zatytułowaną Teoria.

D. Samoistna wartość informacyjna (naukowa i dydaktyczna) wstępu i części teoretycznej [Puppel 2014: 11-76]

Szczególnie chodzi tu o paragrafy traktujące o historii badań nad komunikacją niewerbalną, definicjach gestów, ich typologiach itd. (są to obszary wciąż jeszcze stosunkowo mało znane na gruncie polskim).

E. Rozległe zaplecze erudycyjne rozprawy

Wykaz multidyscyplinarnej (z zakresu językoznawstwa, kulturoznawstwa, socjologii, psychologii, etnologii itd.) literatury przedmiotu [Puppel 2014: 
548-563] liczy 358 pozycji, z czego większość, gdyż 210 pozycji, stanowią książki, czasem wielotomowe. Jak przystało na anglistkę i badaczkę komunikacji niewerbalnej, autorka w największym stopniu wyzyskała naukową literaturę anglojęzyczną (248 pozycji, wobec 100 pozycji polskojęzycznych, obejmujących też przekłady najgłośniejszych dzieł anglosaskich); jest w tym zestawie bibliograficznym także sześć pozycji francuskojęzycznych i pojedyncze włoskie, niemieckie i rosyjskie. W sumie można zasadnie stwierdzić, że rozprawa Joanny Puppel jest gruntownie osadzona w literaturze naukowej o charakterze globalnym. Ta obszerna literatura, umiejętnie wyzyskana przez autorkę, jest wyraźnie obecna w jej rozprawie jako wieloraki kontekst naukowy jej własnych tez i konstatacji, stanowiąc zarazem o gruntowności jej książki i jej zakorzenieniu w złożonej, interdyscyplinarnej problematyce badawczej.

F. Bogactwo analiz i interpretacji

Przypomnijmy, że analizy i interpretacja autorki odnosiły się do 416 rzeźb sakralnych; dzięki zastosowanemu stałemu schematowi interpretacyjnemu są one w całej rozciągłości porównywalne [Puppel 2014: 79-543].

\section{G. Zalety warsztatu naukowego autorki}

Odznacza się on wieloma pożądanymi cechami, wśród których na szczególne podkreślenie zasługują dwie: właściwe miejsce empirii, wyrażające się solidną podstawą źródłowo-materiałową, oraz ostrożność w wyciąganiu wniosków i formułowaniu tez.

H. Ważne i interesujące wyniki naukowe

Do najważniejszych zaliczyłbym potwierdzenie (bo trudno by tutaj było mówić o odkrywaniu czy skonstatowaniu), na oryginalnym materiale, tezy o holistycznym charakterze ludzkiej kompetencji kulturowo-językowo-komunikacyjnej. Badania autorki dowodzą integralności „,zasobów werbalnych i niewerbalnych człowieka, które stapiają się niejako w każdym akcie komunikacyjnym w jedną całość, podporządkowaną całościowemu charakterowi ludzkiego dyskursu jako podstawowego wymiaru ludzkiej performatywności” [Puppel 2014: 547]. Trafnie (choć na dość wysokim poziomie ogólności) scharakteryzowała też badaczka podstawową funkcję rzeźb sakralnych w przestrzeni świątyni katolickiej:

Miały one i nadal mają - w długiej perspektywie czasowej - do odegrania istotną rolę, polegającą na długotrwałym ideowym oddziaływaniu na określony stan świadomości przebywających w tej przestrzeni komunikatorów 
poprzez swoją niezmienność, wzajemną przestrzenną bliskość i wyrazistość tak charakterystyczną dla gestowości o charakterze rytualnym, zawartej w tym przypadku w gestosferze rytualnej zamkniętej przestrzeni świątyni katolickiej i będącej jednocześnie częścią uniwersalnej gestosfery rytualnej człowieka. [Puppel 2014: 545]

Natomiast trochę niedosytu pozostawiają wyniki badań autorki nad frekwencją (powtarzalnością) określonych gestów rytualnych bądź całych, jak to określa autorka, aranżacji gesturalnych. Owszem, opis samego występowania (częstości) poszczególnych matryc jest wyczerpujący i kompletny, jednak w zakresie percepcji gestów (ich wyrazistości czy dystynktywności) autorka ograniczyła się do ankietowego (30 respondentów) przebadania trzech gestów. Wyniki są interesujące (wynika z nich, że największą wyrazistością - siłą dystynktywną - odznaczają się gesty wymagające większego wysiłku motorycznego), choć tylko wstępne i częściowe. Można mieć nadzieję, że autorka w osobnych publikacjach będzie kontynuować takie badania, obejmując nimi kolejne grupy gestów i ,aranżacji gesturalnych”.

Jestem głęboko przekonany, że dzięki wyżej wskazanym zaletom monografia Joanny Puppel znajdzie poczesne miejsce w trwałym dorobku językoznawstwa polskiego. 